\title{
XRD and DTA Analysis of Developed Agglomerated Fluxes for Submerged Arc Welding
}

\author{
Ajay Kumar, ${ }^{1}$ Hari Singh, ${ }^{2}$ and Sachin Maheshwari ${ }^{3}$ \\ ${ }^{1}$ Department of Mechanical Engineering, Noida Institute of Engineering and Technology, Greater Noida 201306, India \\ ${ }^{2}$ Department of Mechanical Engineering, National Institute of Technology, Kurukshetra, Haryana 136119, India \\ ${ }^{3}$ Division of MPAE, Netaji Subhas Institute of Technology, New Delhi 110078, India \\ Correspondence should be addressed to Ajay Kumar; ajayagrohi@gmail.com
}

Received 21 December 2012; Revised 9 February 2013; Accepted 11 February 2013

Academic Editor: Gerhard Sauthoff

Copyright (C) 2013 Ajay Kumar et al. This is an open access article distributed under the Creative Commons Attribution License, which permits unrestricted use, distribution, and reproduction in any medium, provided the original work is properly cited.

\begin{abstract}
A unique study of structural and chemical analysis of crystalline phases in developed agglomerated fluxes was carried out. Thirtytwo fluxes were developed by using a mixture of oxides, halides, carbonates, silicates, and ferroalloys for submerged arc welding. The present paper focuses on only ten (out of thirty-two) fluxes which were analyzed by X-ray diffraction (XRD) to know the different types of oxides formed and changed in oxidation number of metallic centers after sintering process at around $850^{\circ} \mathrm{C}$. To know the effect of temperature over phase transformation and melting of different compounds, differential thermal analysis (DTA) was carried out from 1000 to $1400^{\circ} \mathrm{C}$. This study aims to know the quantity of ions present (percentage) and melting behavior of developed agglomerated fluxes for submerged arc welding process.
\end{abstract}

\section{Introduction}

The agglomeration method is used for flux preparation by using a mixture of oxides, halides, carbonates, silicates, and ferroalloys [1]. The chemistry of weld metal is always governed by the electrochemical changes at the weld pool flux interface because the important properties of submerged arc welding fluxes are the function of their physiochemical properties [2-5]. The important chemical reactions take place during heating of ceramic oxide which is the chemical reaction among the different phases [6], phase transformation of minerals [7], formation of crystalline phases [8], and chemical and structural characterization of crystalline phases in agglomerated fluxes for submerged arc welding were observed [9]. Therefore, the developed agglomerated fluxes can be analyzed to know their crystal structure observed during the rise of temperature. The objective of this analysis is to know the crystalline phases as well as to quantify the different types of ions and their distribution in developed agglomerated fluxes (AGF1101-AGF1110) by X-ray diffraction
(XRD) and differential thermal analysis (DTA) is used to know the peaks of endothermic temperatures.

\section{Experimentation}

In the present study, the fluxes have been designed on the basis of binary and ternary phase diagrams for different oxide and fluoride systems [10] and formulated by using response surface methodology technique [11, 12]. In these fluxes, varying amount of oxides and fluorides were added to know the crystalline phases as well as to quantify the different types of ions and their distribution in developed agglomerated fluxes (AGF1101-AGF1110) by X-ray diffraction (XRD) and differential thermal analysis (DTA) was carried out to know the peaks of endothermic temperatures.

$\mathrm{CaO}-\mathrm{Al}_{2} \mathrm{O}_{3}-\mathrm{SiO}_{2}$-based flux systems have been selected for the study as these are the most widely used fluxes at the commercial level. The details of basic constituents, alloying constituents, and their percentage in the developed agglomerated fluxes are reported in Table 1. 
TABLE 1: Constituents and their ranges.

\begin{tabular}{lcccccccc}
\hline Basic constituents and alloying constituents & $\mathrm{CaO}$ & $\mathrm{SiO}_{2}$ & $\mathrm{Al}_{2} \mathrm{O}_{3}$ & $\mathrm{MnO}$ & $\mathrm{CaF}_{2}$ & $\mathrm{MgO}$ & $\mathrm{NiO}$ & $\mathrm{Fe}-\mathrm{Cr}$ \\
\hline Amount (wt \%) & 20 & 35 & 10 & $5-10$ & $10-20$ & $5-15$ & $0-10$ & $0-10$ \\
\hline
\end{tabular}

TABLE 2: Crystalline phases and crystal structure in developed agglomerated fluxes.

\begin{tabular}{|c|c|c|}
\hline Flux number & Crystalline phase & Crystal structure \\
\hline AFG1101 & $\mathrm{CaAl}_{2} \mathrm{SiO}_{8}($ Dmisteinbergite $)$ & Hexagonal \\
\hline AFG1101 & $\mathrm{Mg}_{7} \mathrm{Fe}_{7} \mathrm{Si}_{8} \mathrm{O}_{22}(\mathrm{OH})_{2}$ (Protoanthrophyllite) & Orthorhombic \\
\hline $\begin{array}{l}\text { AFG1101 } \\
\text { AFG1104 }\end{array}$ & $\mathrm{CaAl}_{2} \mathrm{Si}_{6} \mathrm{O}_{16} \cdot 5\left(\mathrm{H}_{2} \mathrm{O}\right)$ (Epistilbite) & Triclinic \\
\hline AFG1101 & $\mathrm{Mg}_{2} \mathrm{Al}_{2} \mathrm{Si}_{4} \mathrm{O}_{10}(\mathrm{OH}) \cdot 4\left(\mathrm{H}_{2} \mathrm{O}\right)$ (Palygorskite) & Monoclinic \\
\hline AFG1101 & $\mathrm{Ca}_{2} \mathrm{Fe}^{+++}\left(\mathrm{Fe}^{+++}, \mathrm{Al}_{2}\left(\mathrm{SiO}_{4}\right)\left(\mathrm{Si}_{2} \mathrm{O}_{7}\right)(\mathrm{O}, \mathrm{OH})_{2} \cdot \mathrm{H}_{2} \mathrm{O}\right.$ (Julgoldite) & Monoclinic \\
\hline AFG1102 & $\mathrm{CaAl}_{2} \mathrm{Si}_{2} \mathrm{O}_{8}$ (Svyatoslavite) & Monoclinic \\
\hline AFG1102 & $\mathrm{K}_{2} \mathrm{CaMg}_{2}(\mathrm{Al}, \mathrm{Si})_{36} \mathrm{O}_{72} \cdot 28 \mathrm{H}_{2} \mathrm{O}$ (Mazzite) & Hexagonal \\
\hline $\begin{array}{l}\text { AFG1102 } \\
\text { AFG1103 } \\
\text { AFG1104 }\end{array}$ & $\mathrm{Mg}_{2}\left(\mathrm{Al}, \mathrm{Fe}^{+++}\right)_{3} \mathrm{Si}_{3} \mathrm{AlO}_{10}(\mathrm{OH})_{8}($ Sudoite $)$ & Monoclinic \\
\hline AFG1102 & $\mathrm{Mn}_{7} \mathrm{Si}_{3} \mathrm{O}_{12}(\mathrm{OH})_{2}$ (Leucophoenicite) & Monoclinic \\
\hline AFG1102 & $\mathrm{Ca}_{3} \mathrm{Al}_{2}\left(\mathrm{SiO}_{4}\right)_{3-x}(\mathrm{OH})_{4 x}(x=0.2-1.5)$ (Hibschite) & Isometric \\
\hline AFG1104 & $\mathrm{KAl}_{2}\left(\mathrm{Si}_{3} \mathrm{Al}\right) \mathrm{O}_{10}(\mathrm{OH}, \mathrm{F})_{2}$ (Muscovite) & Monoclinic \\
\hline $\begin{array}{l}\text { AFG1104 } \\
\text { AFG1107 } \\
\text { AFG1108 }\end{array}$ & $\mathrm{Ca}_{2}\left(\mathrm{Mn}, \mathrm{Fe}^{++}\right) \mathrm{Fe}^{+++} \mathrm{Si}_{5} \mathrm{O}_{14}(\mathrm{OH})$ (Manganbabingtonite) & Triclinic \\
\hline $\begin{array}{l}\text { AFG1103 } \\
\text { AFG1110 }\end{array}$ & $\mathrm{Ca}_{10} \mathrm{Mg}_{4} \mathrm{Al}_{2} \mathrm{Si}_{11} \mathrm{O}_{39} \cdot 4\left(\mathrm{H}_{2} \mathrm{O}\right)$ (Juanite) & Orthorhombic \\
\hline $\begin{array}{l}\text { AFG1105 } \\
\text { AFG1109 }\end{array}$ & $\mathrm{Ca}_{5} \mathrm{Si}_{2} \mathrm{O}_{7}\left(\mathrm{CO}_{3}\right)_{2}$ (Tilleyite) & Monoclinic \\
\hline $\begin{array}{l}\text { AFG1104 } \\
\text { AFG1108 }\end{array}$ & $\mathrm{Mg}_{9}\left(\mathrm{SiO}_{4}\right)_{4}(\mathrm{OH}, \mathrm{F})_{2}($ Hydroxyl clinotumite $)$ & Monoclinic \\
\hline AFG1108 & $\mathrm{Ca}_{7}\left(\mathrm{SiO}_{4}\right)_{3}(\mathrm{OH})_{2}($ Chegemite $)$ & Orthorhombic \\
\hline AFG1110 & $\mathrm{Ca}_{14}\left(\mathrm{Mn}^{++}\right)_{14} \mathrm{Si}_{24} \mathrm{O}_{58}(\mathrm{OH})_{8} \cdot 2\left(\mathrm{H}_{2} \mathrm{O}\right)($ Truscottite $)$ & Triclinic \\
\hline AFG1110 & $\mathrm{CaO} \cdot 3\left(\mathrm{Fe}^{++}, \mathrm{Mg}, \mathrm{Fe}^{+++}\right)_{3} \mathrm{Si}_{4} \mathrm{Al}_{4} \mathrm{O}_{10}(\mathrm{OH})_{2} \cdot 4\left(\mathrm{H}_{2} \mathrm{O}\right)$ (Ferrosaponite) & Monoclinic \\
\hline AFG1110 & $\mathrm{Ca}_{4} \mathrm{Si}_{2} \mathrm{O}_{6} \mathrm{CO}_{3}(\mathrm{OH}, \mathrm{F})_{2}$ (Fukalite $)$ & Orthorhombic \\
\hline AFG1105 & $\mathrm{Mg}_{5}\left(\mathrm{Fe}^{+++}\right)_{5}\left(\mathrm{SiO}_{4}\right)_{2}(\mathrm{OH}, \mathrm{F})_{2}($ Chondrodite $)$ & Monoclinic \\
\hline
\end{tabular}

TABLE 3: Quantity of oxides in percentage weight for developed agglomerated fluxes.

\begin{tabular}{|c|c|c|c|c|c|c|c|c|c|c|c|}
\hline \multirow{2}{*}{ Serial number } & \multirow{2}{*}{ Oxides } & \multicolumn{10}{|c|}{ Quantity of oxides present (wt.\%) in developed agglomerated fluxes } \\
\hline & & AFG1101 & AFG1102 & AFG1103 & AFG1104 & AFG1105 & AFG1106 & AFG1107 & AFG1108 & AFG1109 & AFG1110 \\
\hline 1 & $\mathrm{CaO}$ & 8.29 & 12.48 & 28.10 & 5.76 & 11.47 & 9.33 & 4.89 & 17.21 & 14.65 & 24.53 \\
\hline 2 & $\mathrm{SiO}_{2}$ & 58.80 & 31.16 & 42.38 & 5.71 & 21.19 & 38.57 & 21.79 & 31.27 & 12.65 & 33.12 \\
\hline 3 & $\mathrm{Al}_{2} \mathrm{O}_{3}$ & 10.50 & 22.94 & 14.30 & 18.29 & 24.18 & 16.66 & 11.32 & 23.39 & 20.00 & 3.27 \\
\hline 4 & $\mathrm{MgO}$ & 7.80 & 3.37 & 8.12 & 14.47 & 29.78 & 6.59 & 5.78 & 17.34 & 18.52 & 3.37 \\
\hline 5 & $\mathrm{MnO}$ & 0.02 & 14.29 & - & 1.86 & - & - & 2.32 & 1.85 & - & 21.20 \\
\hline 6 & $\mathrm{NiO}$ & 0.02 & - & - & - & - & - & - & - & - & - \\
\hline 7 & $\mathrm{FeO}$ & 0.91 & 0.26 & 0.44 & 0.89 & - & 3.91 & 0.78 & 0.63 & - & 4.20 \\
\hline 8 & $\mathrm{Fe}_{2} \mathrm{O}_{3}$ & 6.47 & 0.58 & 0.64 & 3.37 & - & - & 3.48 & 2.79 & - & 1.73 \\
\hline 9 & $\mathrm{Na}_{2} \mathrm{O}$ & 0.04 & - & - & - & - & - & - & - & - & 0.48 \\
\hline 10 & $\mathrm{CO}_{2}$ & - & - & - & - & 5.41 & 7.82 & 6.31 & - & 13.57 & 2.15 \\
\hline 11 & $\mathrm{MnO}_{2}$ & - & - & - & - & - & 16.66 & - & - & - & - \\
\hline
\end{tabular}



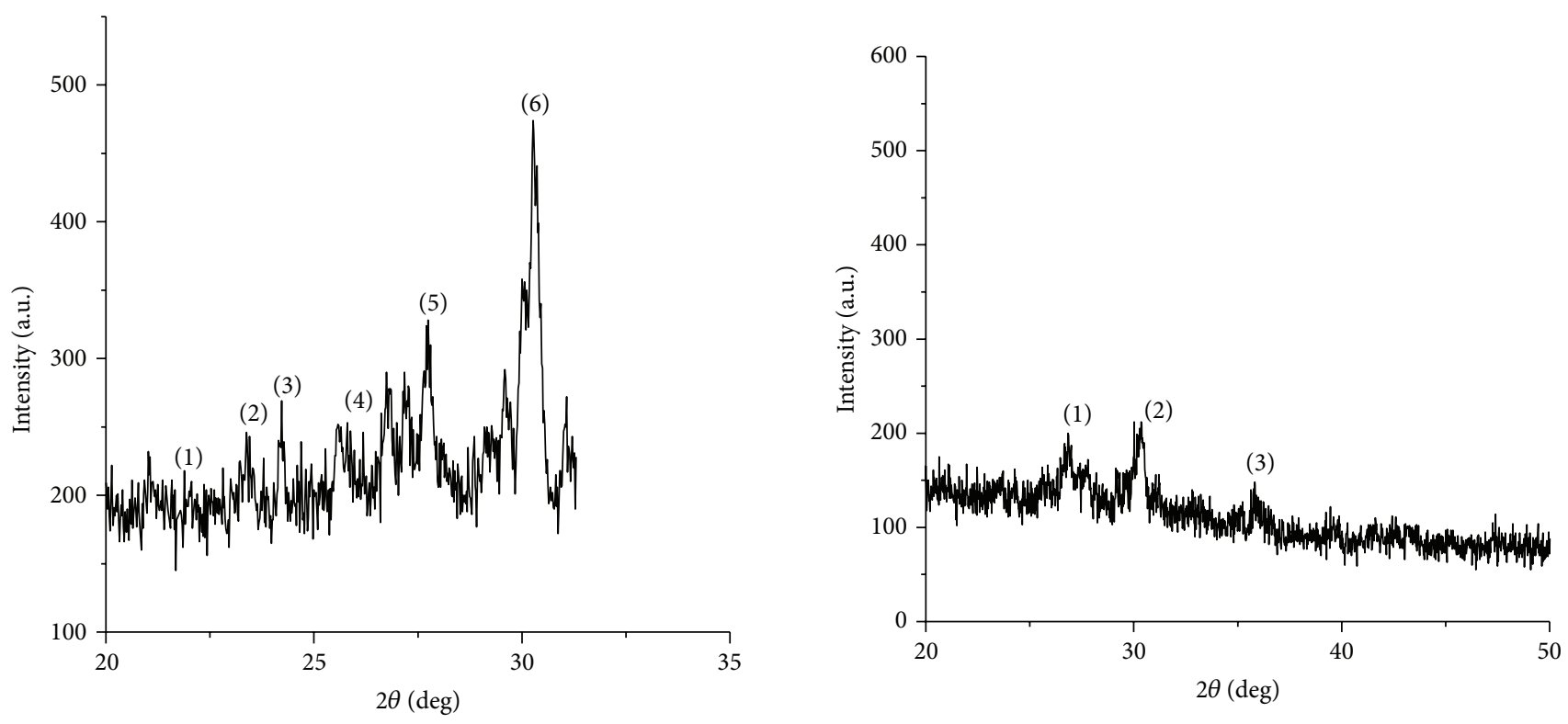
(1) $\mathrm{SiO}_{2}$
(2) $\mathrm{CaAl}_{2} \mathrm{Si}_{2} \mathrm{O}_{8}$
(3) $\mathrm{Mg}_{7} \mathrm{Fe}_{7} \mathrm{Si}_{8} \mathrm{O}_{22}(\mathrm{OH})_{2}$
(4) $\mathrm{CaAl}_{2} \mathrm{Si}_{6} \mathrm{O}_{16} \cdot 5 \mathrm{H}_{2} \mathrm{O}$
(5) $\mathrm{Mg}_{2} \mathrm{Al}_{2} \mathrm{Si}_{4} \mathrm{O}_{10}(\mathrm{OH}) \cdot 4 \mathrm{H}_{2} \mathrm{O}$
(6) $\mathrm{Ca}_{2} \mathrm{Fe}^{+++}\left(\mathrm{Fe}^{+++}, \mathrm{Al}_{2} \mathrm{SiO}_{4}\left(\mathrm{Si}_{2} \mathrm{O}_{7}(\mathrm{O}, \mathrm{OH})_{2} \cdot \mathrm{H}_{2} \mathrm{O}\right.\right.$

FIGURE 1: XRD graph of AGF1101 flux.
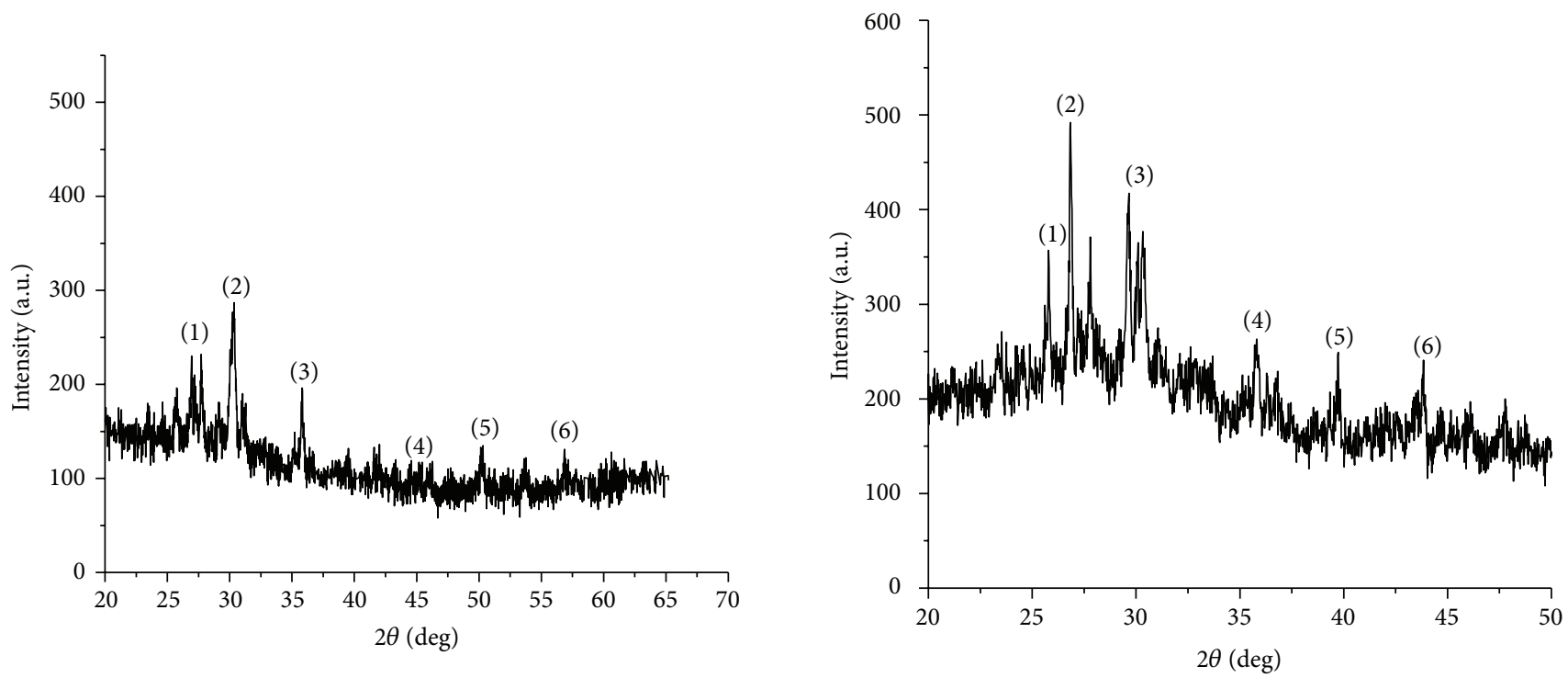
(1) $\mathrm{CaAl}_{2} \mathrm{Si}_{2} \mathrm{O}_{8}$
(2) $\mathrm{K}_{2} \mathrm{CaMg}_{2} \mathrm{Al}_{36} \mathrm{Si}_{36} \mathrm{O}_{72} \cdot 28\left(\mathrm{H}_{2} \mathrm{O}\right)$
(3) $\mathrm{Mg}_{2}\left(\mathrm{Al}, \mathrm{Fe}^{+++}\right)_{3} \mathrm{Si}_{3} \mathrm{AlO}_{10}(\mathrm{OH})_{8}$
(4) $\mathrm{Fe}, \mathrm{Ni}$
(5) $\mathrm{Mn}_{7}\left(\mathrm{SiO}_{4}\right)_{3}(\mathrm{OH})_{2}$
(6) $\mathrm{Ca}_{3} \mathrm{Al}_{2}\left(\mathrm{SiO}_{4}\right)_{3} \cdot X(\mathrm{OH})_{4 X}(X=0.2-1.5)$

FIGURE 2: XRD graph of AGF1102 flux.

(1) $\mathrm{CaAl}_{2} \mathrm{Si}_{6} \mathrm{O}_{16} \cdot 5\left(\mathrm{H}_{2} \mathrm{O}\right)$

(2) $\mathrm{KAl}_{2}\left(\mathrm{Si}_{3} \mathrm{Al}\right) \mathrm{O}_{10}(\mathrm{OH}, \mathrm{F})_{2}$

(3) $\mathrm{Ca}_{2}\left(\mathrm{Mn}, \mathrm{Fe}^{++}\right) \mathrm{Fe}^{+++} \mathrm{Si}_{5} \mathrm{O}_{14}(\mathrm{OH})$

(4) $\mathrm{Mg}_{2}\left(\mathrm{Al}, \mathrm{Fe}^{+++}\right)_{3} \mathrm{Si}_{3} \mathrm{Al}_{10}(\mathrm{OH})_{8}$

(5) $\mathrm{Mg}_{9}\left(\mathrm{SiO}_{4}\right)_{4}(\mathrm{OH}, \mathrm{F})_{2}$

(6) $\mathrm{Mn}_{5} \mathrm{Si}_{3}$

FIGURE 4: XRD graph of AGF1104 flux. 


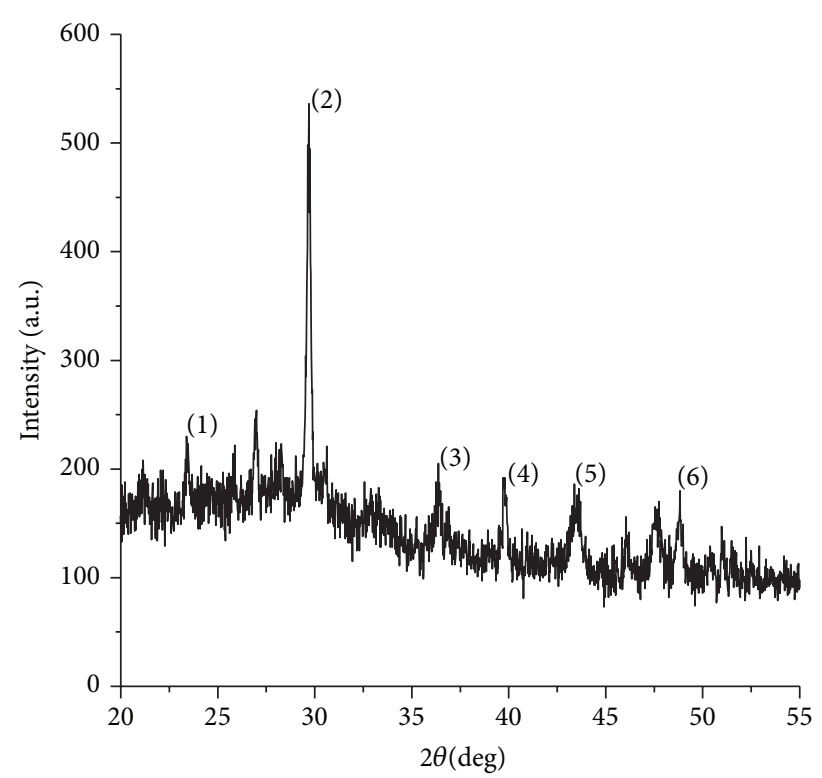

(1) $\mathrm{Mg}_{4} \mathrm{Al}_{2}(\mathrm{OH})_{12} \mathrm{Co}_{3} \cdot 4\left(\mathrm{H}_{2} \mathrm{O}\right)$

(2) $\mathrm{Ca}_{5} \mathrm{Si}_{2} \mathrm{O}_{7}\left(\mathrm{Co}_{3}\right)_{2}$

(3) $\mathrm{Mg}_{2} \mathrm{SiO}_{4}$

(4) $\mathrm{Mg}_{9}\left(\mathrm{SiO}_{4}\right) 4(\mathrm{OH}, \mathrm{F})_{2}$

(5) $\mathrm{Al}_{2} \mathrm{O}_{3}$

FIGURE 5: XRD graph of AGF1105 flux.

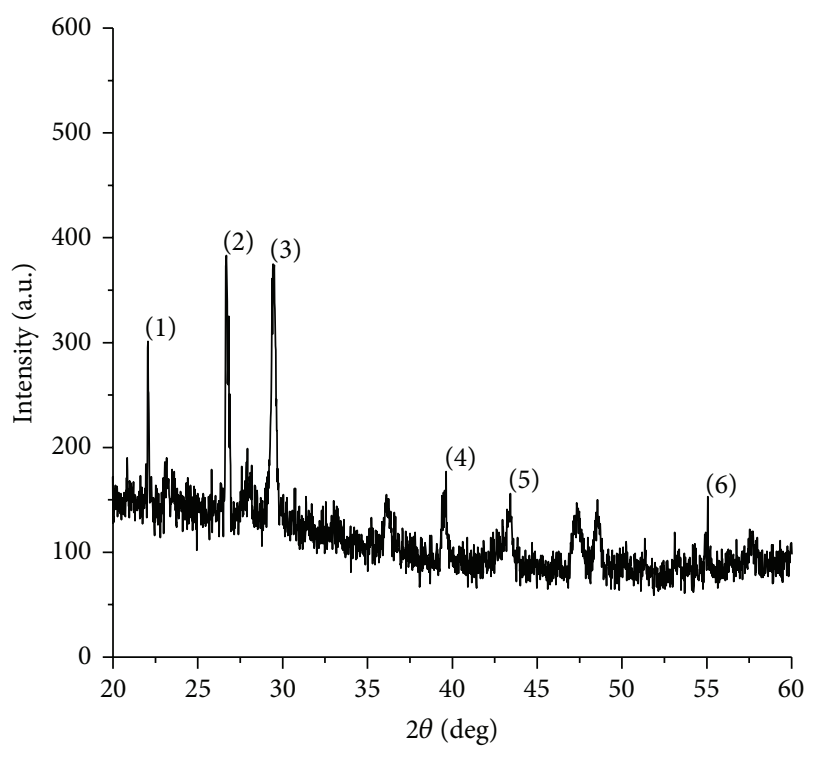

(1) $\mathrm{SiO}_{2}$

(2) $\mathrm{SiO}_{2}$

(3) $\mathrm{CaCo}_{3}$

(4) $\left(\mathrm{Mg}, \mathrm{Fe}^{++}\right)_{5}\left(\mathrm{SiO}_{4}\right)_{2}(\mathrm{~F}, \mathrm{OH})_{2}$

(5) $\mathrm{Al}_{2} \mathrm{O}_{3}$

(6) $\mathrm{MnO}_{2}$

FIGURE 6: XRD graph of AGF1106 flux.
TABLE 4: DTA analysis for endothermic temperatures.

\begin{tabular}{lc}
\hline Flux & $\begin{array}{c}\text { Peaks of endothermic } \\
\text { temperature }\left({ }^{\circ} \mathrm{C}\right)\end{array}$ \\
\hline AGF1101 & 1239.89 \\
AGF1102 & 1234.25 \\
AGF1103 & 1233.58 \\
AGF1104 & 1240.77 \\
AGF1105 & 1226.99 \\
AGF1106 & 1334.85 \\
AGF1107 & 1244.58 \\
AGF1108 & 1191.77 \\
AGF1109 & 1245.84 \\
AGF1110 & 1248.37 \\
\hline
\end{tabular}

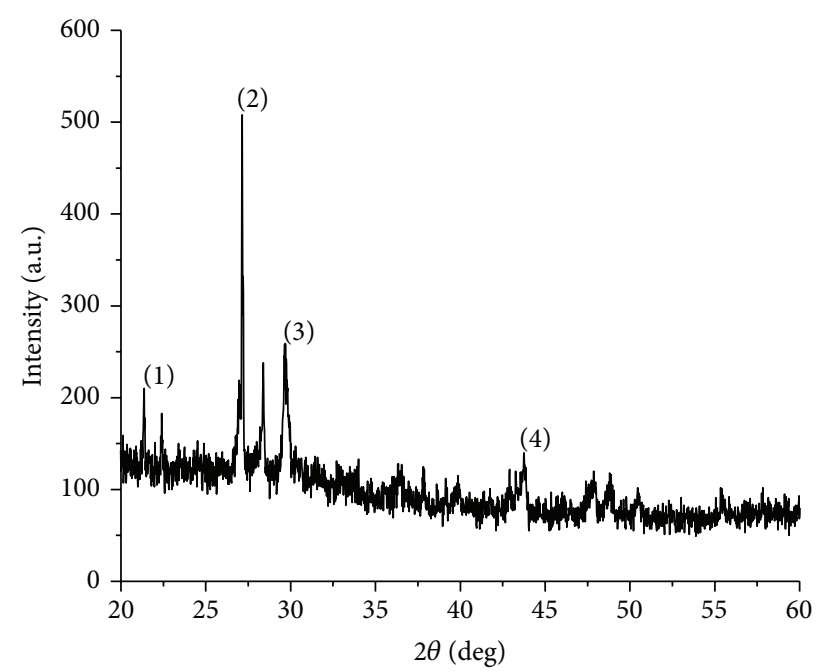

(1) $\mathrm{MgCo}_{3} \cdot 5\left(\mathrm{H}_{2} \mathrm{O}\right)$

(2) $\mathrm{Al}_{2} \mathrm{O}_{3} \cdot\left(\mathrm{SiO}_{2}\right)_{1.3-2} \cdot\left(\mathrm{H}_{2} \mathrm{O}\right)_{2.5-3}$

(3) $\mathrm{Ca}_{2}\left(\mathrm{M}, \mathrm{Fe}^{++}\right) \mathrm{Fe}^{+++} \mathrm{Si}_{5} \mathrm{O}_{14}(\mathrm{OH})$

(4) $\mathrm{Ni}_{2} \mathrm{Fe}$ to $\mathrm{Ni}_{3} \mathrm{Fe}$

FIGURE 7: XRD graph of AGF1107 flux.

After ascertaining the compositions and constituents of fluxes, they were prepared by agglomeration method by taking small batches $(2 \mathrm{~kg}$ ) of weighed quantities of powdered chemicals except binder and thoroughly mixed in a ball miller. The prepared granular flux was dried and baked in an electrically heated furnace for $3 \mathrm{hrs}$ at $850^{\circ} \mathrm{C}$. The dried flux was allowed to cool down to room temperature before storing it in a moisture free box. The XRD analysis was carried out by diffractometer with the monochromatic light wavelength $1.540600 \AA(\mathrm{Cu} \mathrm{K} \alpha)$ for all developed agglomerated flux. The DTA was carried out in an $\mathrm{Al}_{2} \mathrm{O}_{3}$ crucible from 28 to $1400^{\circ} \mathrm{C}$ at the heating rate of $10^{\circ} \mathrm{C} / \mathrm{min}$. Alumina was used as a standard reference for differential thermal analysis. 


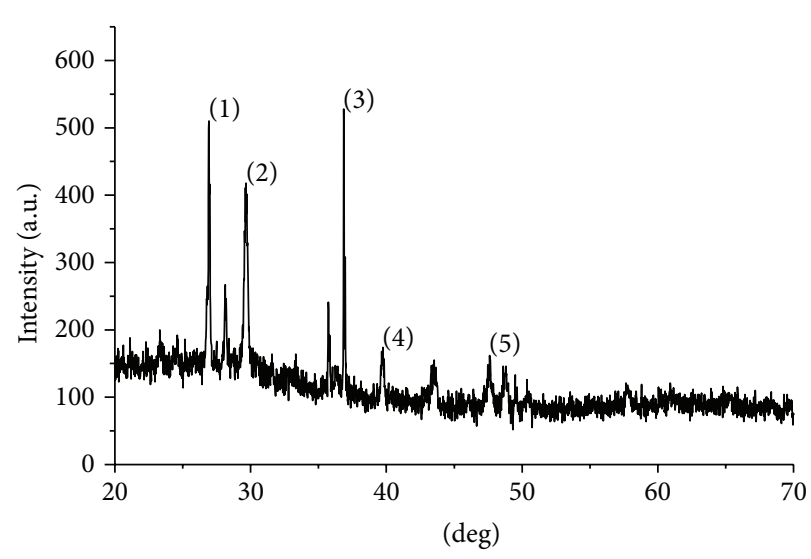

(1) $\mathrm{Al}_{2} \mathrm{O}_{3} \cdot\left(\mathrm{SiO}_{2}\right)_{1.3-2} \cdot\left(\mathrm{H}_{2} \mathrm{O}\right)$

(2) $\mathrm{Ca}_{2}\left(\mathrm{Mn}, \mathrm{Fe}^{++}\right) \mathrm{Fe}^{+++} \mathrm{Si}_{5} \mathrm{O}_{14}(\mathrm{OH})$

(3) $\mathrm{MgAl}_{2} \mathrm{O}_{4}$

(4) $\mathrm{Mg}_{5} \mathrm{Si}_{3}$

(5) $\mathrm{Ca}_{7}\left(\mathrm{SiO}_{4}\right)_{3}(\mathrm{OH})_{2}$

FIGURE 8: XRD graph of AGF1108 flux.

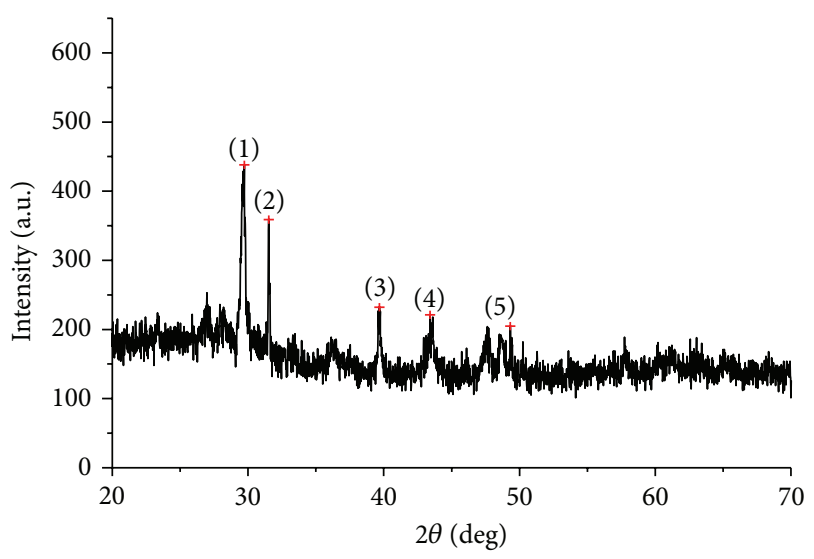

(1) $\mathrm{Ca}_{5} \mathrm{Si}_{2} \mathrm{O}_{7}\left(\mathrm{Co}_{3}\right)$

(2) $\mathrm{CaMg}_{3}\left(\mathrm{Co}_{3}\right)_{4}$

(3) $\mathrm{Mg}_{9}\left(\mathrm{SiO}_{4}\right)(\mathrm{OH}, \mathrm{F})_{2}$

(4) $\mathrm{Al}_{2} \mathrm{O}_{3}$

FIGURE 9: XRD graph of AGF1109 flux.

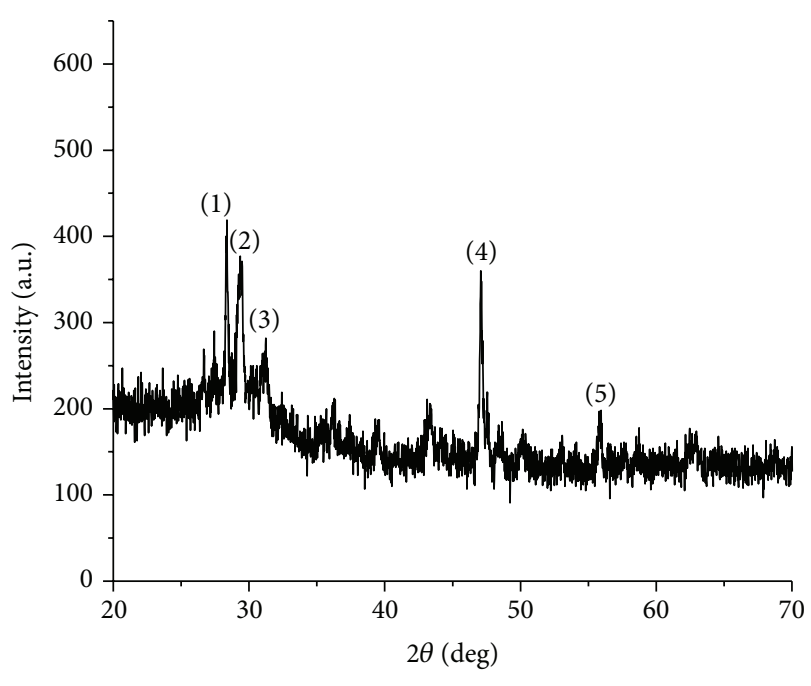

(1) $\left(\mathrm{Ca}, \mathrm{Mn}^{++}\right)_{14} \mathrm{Si}_{24} \mathrm{O}_{58}(\mathrm{OH})_{8} \cdot\left(\mathrm{H}_{2} \mathrm{O}\right)$

(2) $\left(\mathrm{Mn}^{++}\right)_{2} \mathrm{SiO}_{3}(\mathrm{OH})_{2} \cdot\left(\mathrm{H}_{2} \mathrm{O}\right)$

(3) $\mathrm{Ca}_{4} \mathrm{SiO}_{2} \mathrm{O}_{6}\left(\mathrm{CO}_{3}\right)(\mathrm{OH}, \mathrm{F})_{2}$

(4) $\mathrm{Ca}_{10} \mathrm{Mg}_{4} \mathrm{Al}_{2} \mathrm{Si}_{11} \mathrm{O}_{39} \cdot 4\left(\mathrm{H}_{2} \mathrm{O}\right)$

(5) $\mathrm{MnO}_{2}$

FIGURE 10: XRD graph of AGF1110 flux.

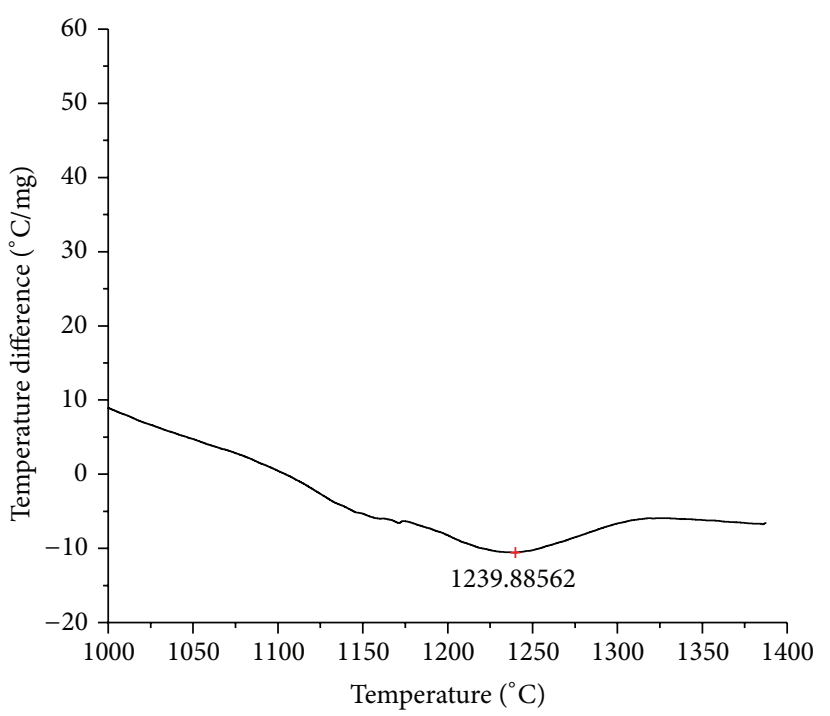

Figure 11: DTA graph of AGF1101 flux.

\section{Result and Discussion}

3.1. XRD and DTA Analysis of Developed Agglomerated Fluxes. The XRD results of developed agglomerated fluxes are shown in Figures 1, 2, 3, 4, 5, 6, 7, 8, 9, and 10 and by these graphs, it has been observed that a number of crystalline phases are formed due to chemical interaction among ions with potassium silicate binder. The oxides like $\mathrm{MnO}, \mathrm{MgO}$, $\mathrm{SiO}_{2}, \mathrm{Al}_{2} \mathrm{O}_{3}$, and $\mathrm{CaO}$ were found in compound form, which means they do not react with one another. The names of different crystalline phases observed in XRD analysis along with their crystal structure were given in Table 2 . The quantity of different oxides shown in Table 3 was based on XRD peaks with high intensity [13]. The development of different types of silicates and oxides is mainly due to mixing of potassium silicate during the agglomeration process.

The curves of differential thermal analysis (DTA) are shown in Figures 11, 12, 13, 14, 15, 16, 17, 18, 19, and 20 and it shows that most of the oxides were stable oxides up to $1000^{\circ} \mathrm{C}$. The ranges of DTA curves were found between 1000 


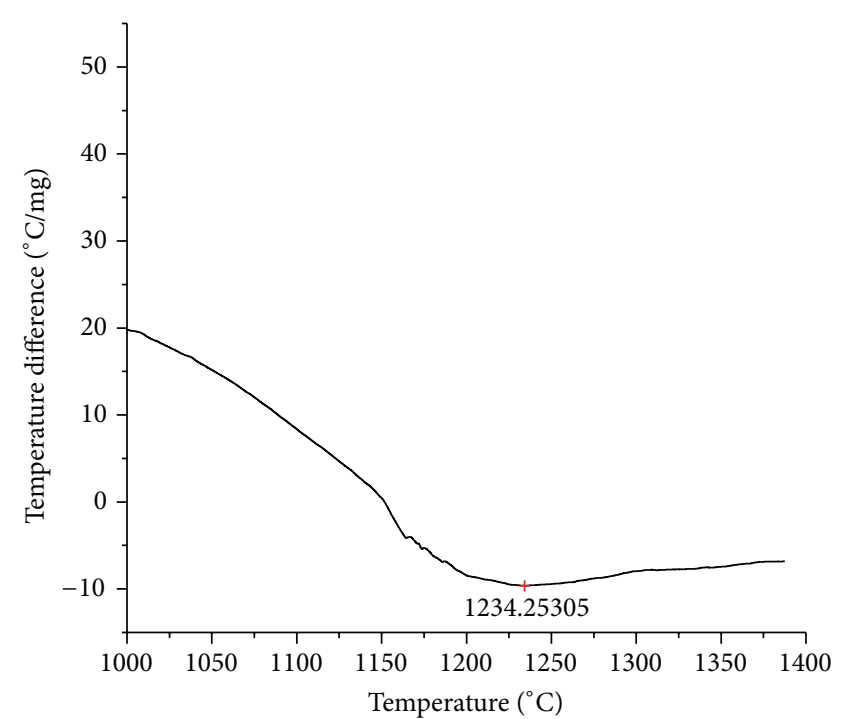

FIGURE 12: DTA graph of AGF1102 flux.

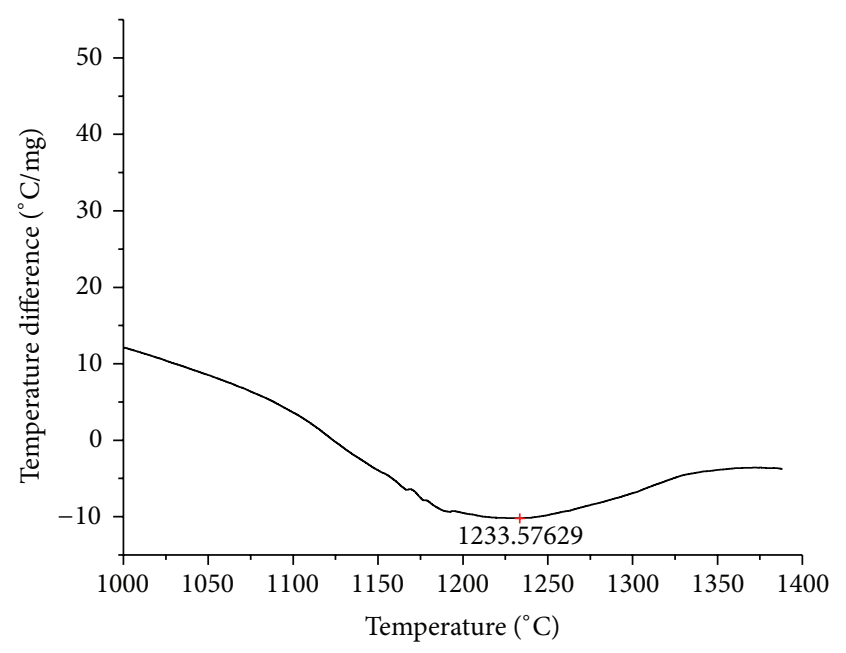

FIGURE 13: DTA graph of AGF1103 flux.

to $1400^{\circ} \mathrm{C}$. With a few exceptions, most of the reactions were endothermic in nature and the endothermic peaks were observed at different temperatures for different fluxes given in Table 4. The endothermic peaks were different for different fluxes because of their different chemical compositions. These endothermic peaks were comparable with the melting reaction of different crystalline phases for different fluxes. In some DTA curves, a zigzag behavior was observed due to gassing or blistering of the glass formation [14]. The anions generally present in the fluxes are $\mathrm{O}^{2-}$ and $\mathrm{F}^{1-}$. The cations from the flux like $\mathrm{Ca}^{2+}, \mathrm{Mg}^{2+}, \mathrm{Al}^{3+}, \mathrm{Fe}^{2+}, \mathrm{Fe}^{3+}, \mathrm{Si}^{4+}, \mathrm{Mn}^{2+}, \mathrm{Mn}^{3+}$, and $\mathrm{Mn}^{4+}$ can react with oxygen and tetrahedral unit $\mathrm{SiO}_{4}{ }^{4-}$ from the silicates formed in the fluxes. Since, calcium and magnesium ions have the largest negative heat of formation energy $\Delta G_{f}$, therefore, they react quickly with oxygen in the welding arch.

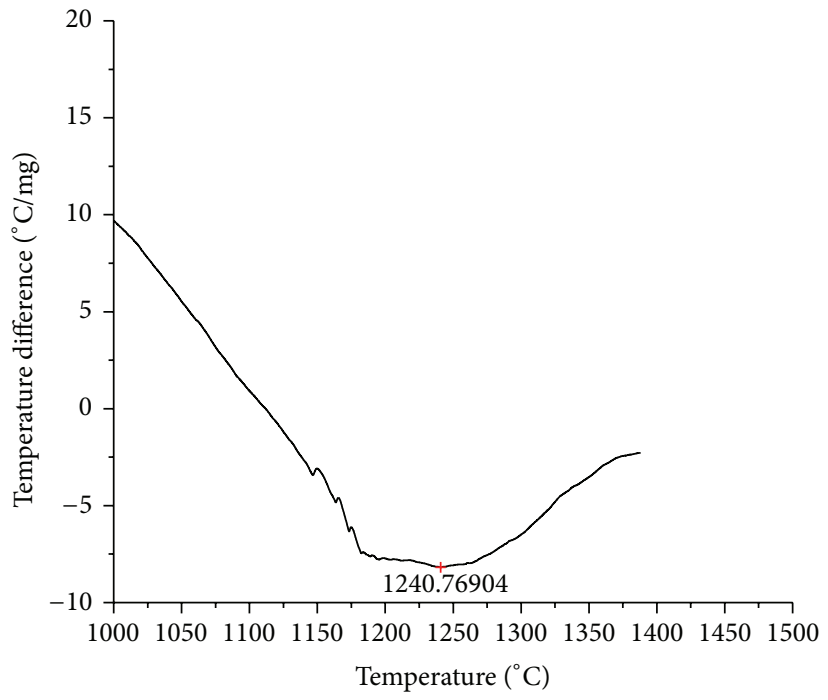

FIGURE 14: DTA graph of AGF1104 flux.

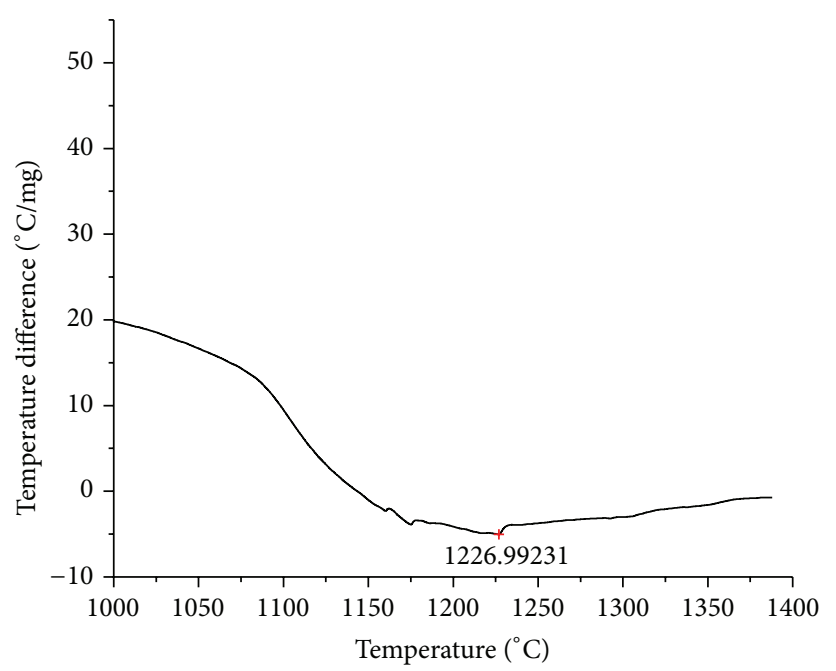

FIGURE 15: DTA graph of AGF1105 flux.

There were changes in oxidation number in some cationic constituents like $\mathrm{Fe}^{2+}, \mathrm{Fe}^{3+}, \mathrm{Mn}^{2+}$, and $\mathrm{Mn}^{4+}$. In most of the fluxes, calcium was present which increases the stability of electric arc during welding. The viscosity of fluxes increases by the presence of corundum and $\mathrm{SiO}_{2}$ which are present in most of the fluxes. In most of the fluxes, it has been observed that the $\mathrm{MnO}$ and $\mathrm{SiO}_{2}$ are jointly present and increase the thermomechanical behavior of weld joint.

\section{Conclusion}

The study identified the quantity of different ions present in the weld pool, and it also helps to know the different types of oxides and probable crystalline phases in developed 


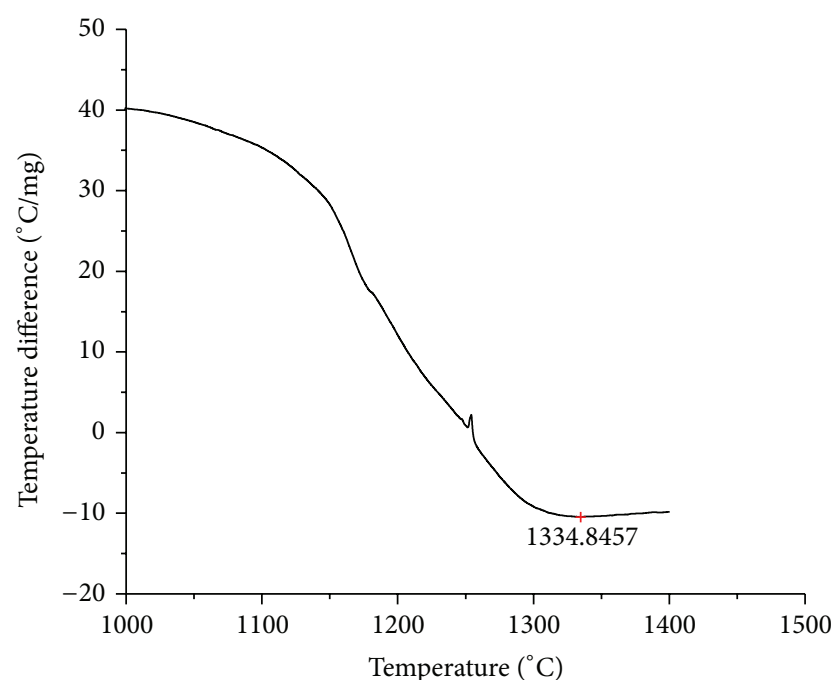

FIGURE 16: DTA graph of AGF1106 flux.



FigUre 17: DTA graph of AGF1107 flux.

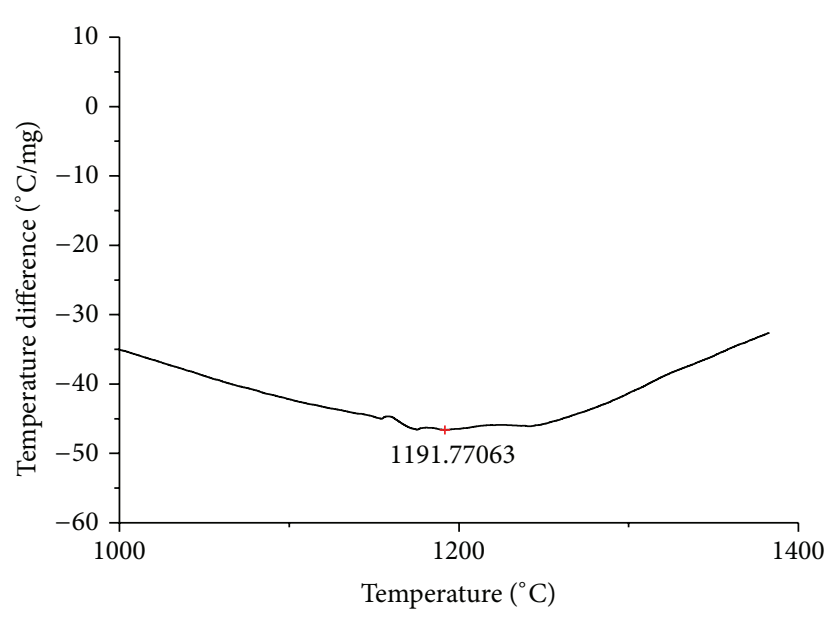

FigURE 18: DTA graph of AGF1108 flux.

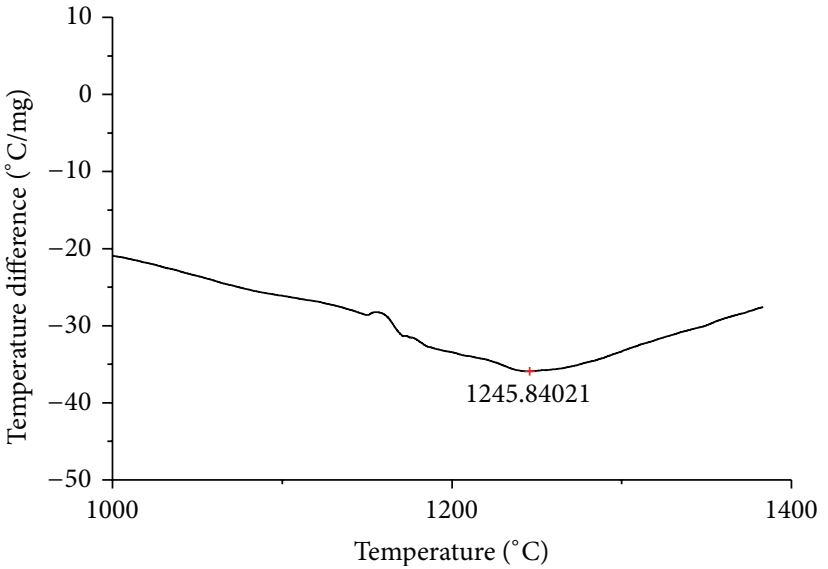

Figure 19: DTA graph of AGF1109 flux.

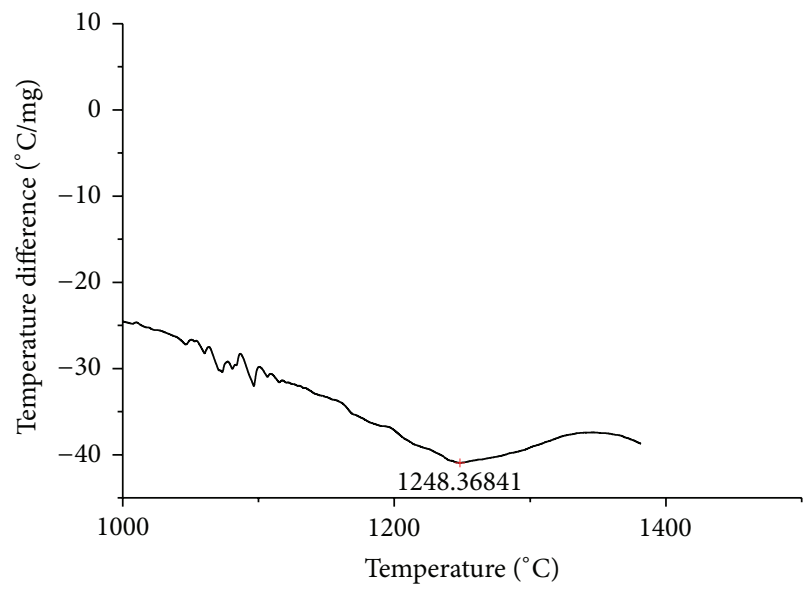

Figure 20: DTA graph of AGF1110 flux.

agglomerated fluxes during submerged arc welding. Such types of studies are very much helpful to know the effect of compositions of fluxes on thermomechanical behavior of weld metal.

\section{References}

[1] J. E. Indacochea, M. Blander, and S. Shah, "Submerged arc welding: evidence for electrochemical effects on the weld pool," Welding Journal, vol. 68, no. 3, pp. 77-79, 1989.

[2] C. E. Jackson, "Submerged-arc welding, fluxes and relations among process variables," in Metals Hand Book, pp. 73-77, ASM, Metals Park, Ohio, USA, 1982.

[3] G. G. Wittstock, "Selecting submerged arc fluxes for carbon and low alloy steels," Welding Journal, vol. 55, pp. 733-741, 1976.

[4] A. M. Paniagua-Mercado, V. M. López-Hirata, and M. L. Saucedo Muñoz, "Influence of the chemical composition of flux on the microstructure and tensile properties of submerged-arc welds," Journal of Materials Processing Technology, vol. 169, no. 3, pp. 346-351, 2005.

[5] P. Kanjilal, T. K. Pal, and S. K. Majumdar, "Combined effect of flux and welding parameters on chemical composition and mechanical properties of submerged arc weld metal," Journal 
of Materials Processing Technology, vol. 171, no. 2, pp. 223-231, 2006.

[6] S. S. Singer, Industrial Ceramics, Chapman \& Hall, London, UK, 1963.

[7] A. W. Allen, "Optical microscopy in ceramic engineering," in Proceedings of the 3rd Berkeley International Materials Conference, Berkeley, Calif, USA, June 1966.

[8] R. H. Redwine and M. A. Conrad, "Microstructures developed in crystallized glass ceramics," in Proceedings of the 3rd Berkeley International Materials Conference, Berkeley, Calif, USA, July 1961.

[9] A. M. Paniagua-Mercado, P. Estrada-Diaz, and V. M. LópezHirata, "Chemical and structural characterization of the crystalline phases in agglomerated fluxes for submerged-arc welding," Journal of Materials Processing Technology, vol. 141, no. 1, pp. 93-100, 2003.

[10] A. Muan and E. F. Osborn, Phase Equilibria among Oxides in Steel Making, Addison-Wesley, Reading, Mass, USA, 1965.

[11] D. C. Montgomery, Design and Analysis of Experiments, Wiley, New Delhi, India, 5th edition, 2007.

[12] A. Kumar, H. Singh, and S. Maheshwari, "Modeling and analysis by response surface methodology of hardness for submerged arc welded joints using developed agglomerated fluxes," Indian Journal of Engineering \& Materials Sciences, vol. 19, pp. 379-385, 2012.

[13] B. D. Cullity, Elements of X-Ray Diffraction, Addison-Wesley, Reading, Mass, USA, 1978.

[14] P. K. Gordon, "Microstructure of complex ceramics," in Proceedings of the 3rd Berkeley International Materials Conference, Berkeley, Calif, USA, July 1966. 

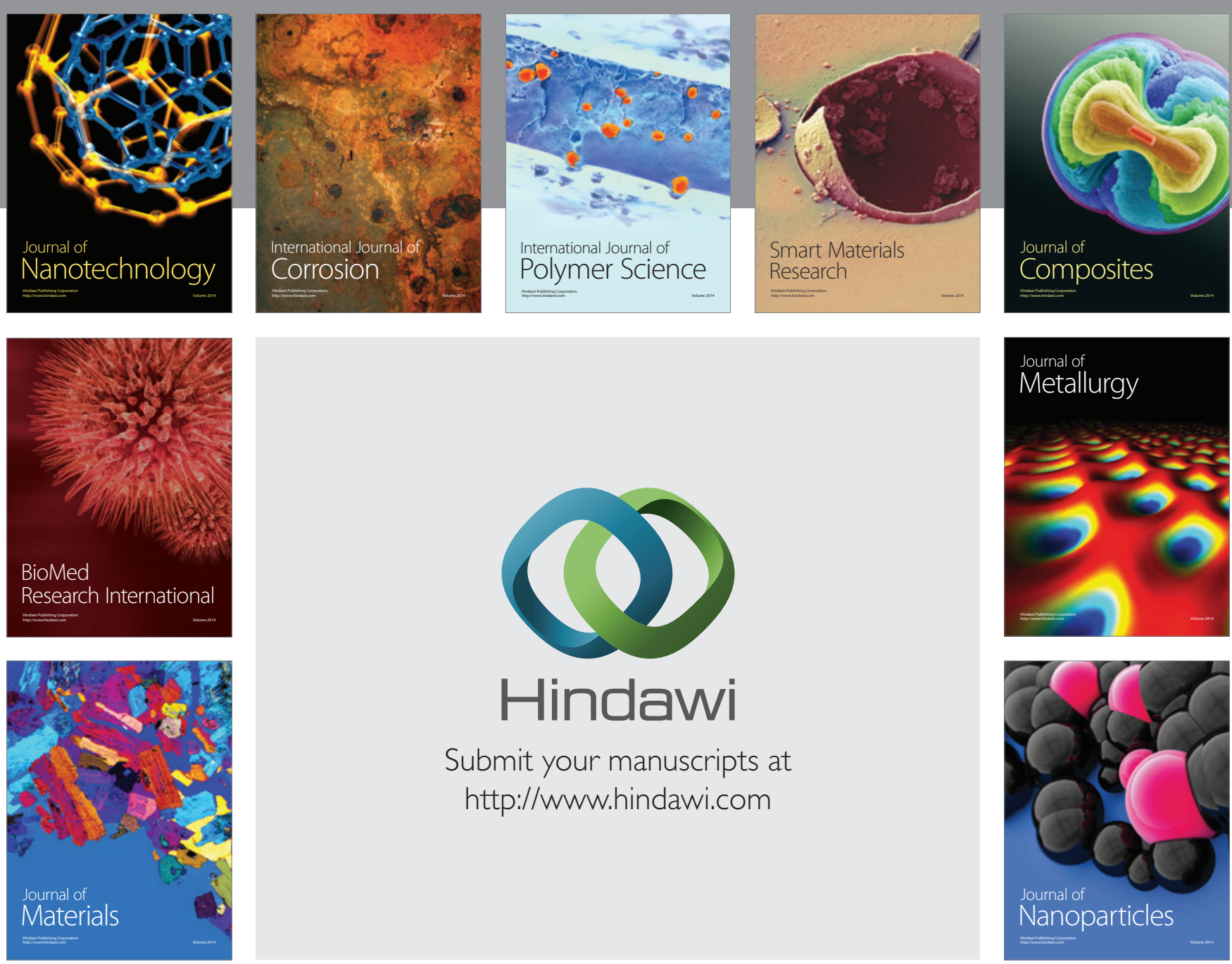

Submit your manuscripts at http://www.hindawi.com
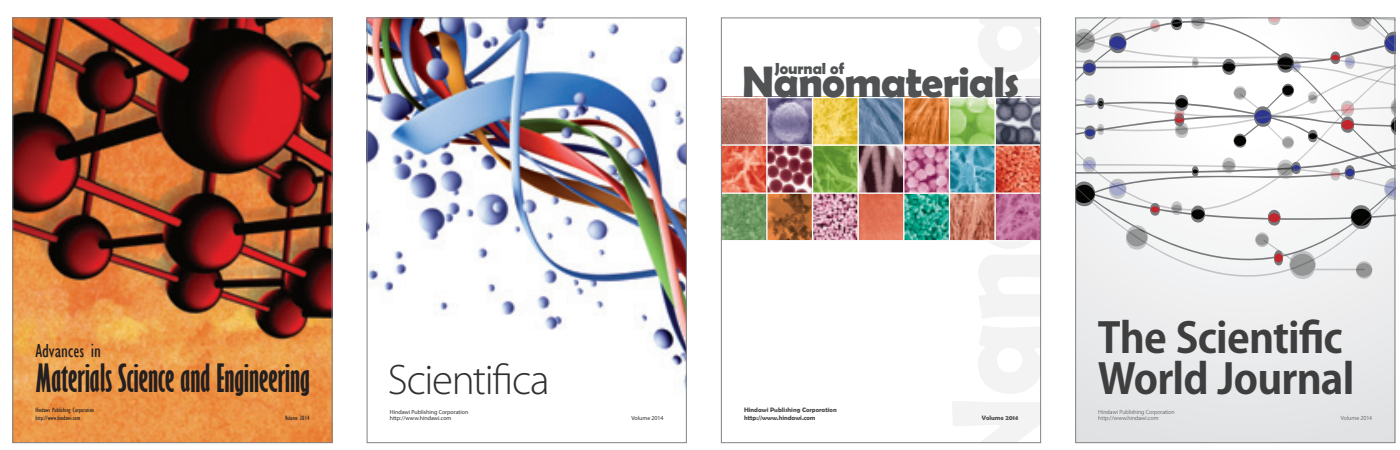

\section{The Scientific World Journal}
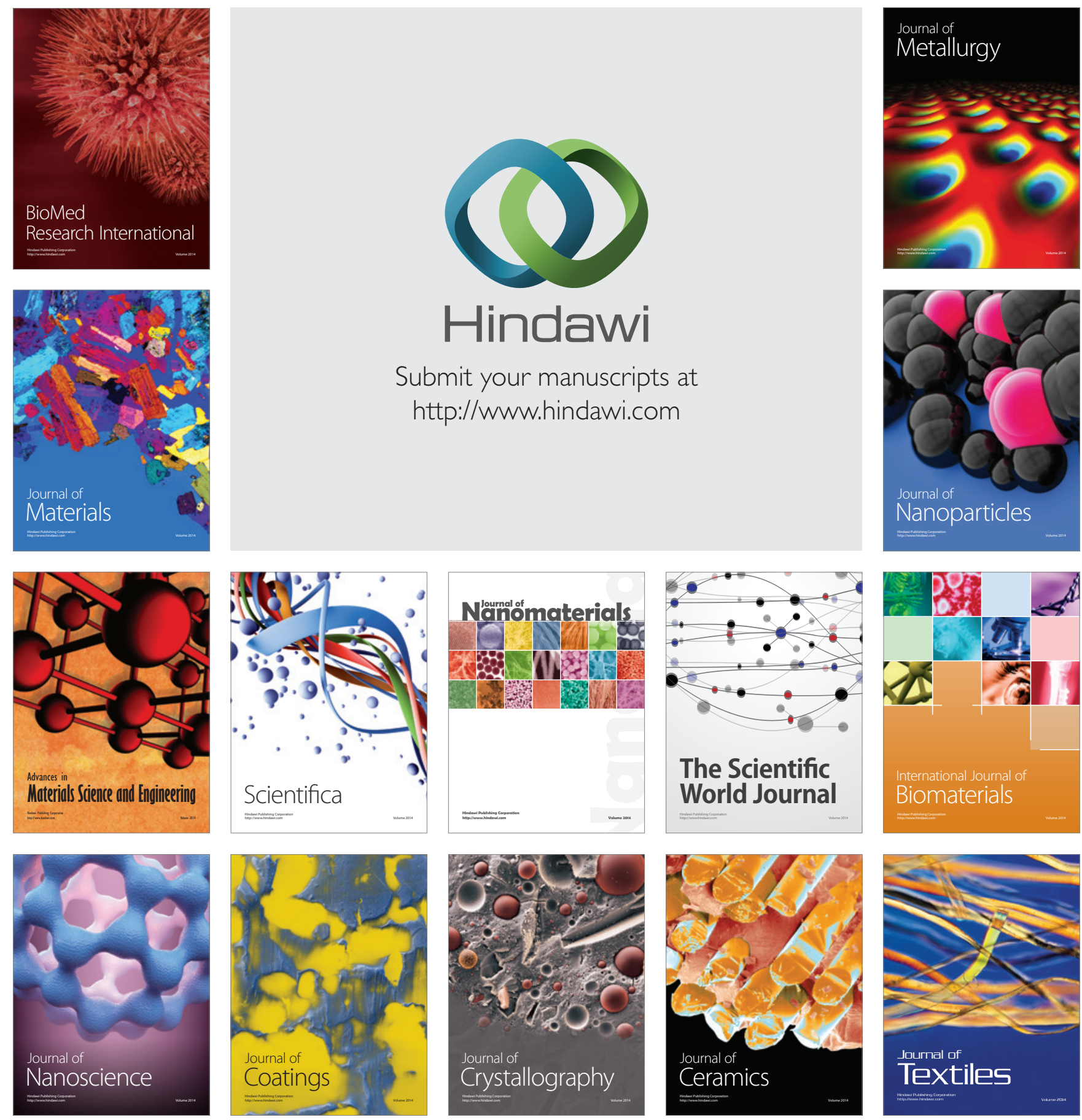